\title{
Analysis of Japanese meeting planners' profiles and site selection
}

Tadayuki Hara (Rosen College of Hospitality Management, University of Central Florida, tadayuki.hara@ucf.edu)

Hidekazu Iwamoto (Faculty of Tourism, Josai International University, iwamoto@jiu.ac.jp)

\begin{abstract}
With support from MPI Japan, we have collected survey responses from active meeting planners in Japan, which revealed their profiles and their perception on priorities regarding meeting site selection criteria. Meeting Professionals International (MPI) is one of the largest meeting planner and event planner industry association worldwide. MPI Japan Chapter was established in 1995. In the results of the questionnaire survey, majority of members are between ages of 35 and 64, and surprisingly overwhelming majority are male. Soft areas such as service and management quality of the venue are deemed more important in their selection of meeting venues, besides ease of access of the venue. The result of our analyses highlights importance of decomposition of MICE into sub-categories to cater to the different needs and perceptions of relative importance of the same issues by meeting planners in Japan.
\end{abstract}

\section{Keywords}

site selection, meeting planner, meeting industry, MICE, questionnaire survey

\section{Introduction}

This study is to clarify the Japanese meeting planners' profiles and their perception of priorities regarding site selection. Convention industry is rapidly emerging as one of the most important segments in the tourism industry. Convention industry is classified as four categories: the acronym, 'MICE' (Meetings, Incentives, Convention/Congress, and Exhibition/Event).

According to Lau, Milne, and Johnson [2005], MICE industry can act as economic hubs (both virtual and real) and bring benefits to the surrounding economy.

Convention/exhibition host cities in these countries are competing to attract the more profitable exhibitions. Japan's relative position of dominant host city for MICE industry in Asia has tended to come down since 2000s because major cities such as Hong Kong, Singapore, Beijing, Shanghai, Seoul in Asia, have been competing for this business at the expense of Japan.

Research on MICE industry has begun since the mid - 1980s and build upon wide research. Two areas of research regarding economic impact and site-selection criteria, have received the most attention [Pearlman and Mollere, 2009]. However, there are shortages of experts such as meeting planners and event producers in Japan. It is not always understood that it is the meeting planner who poses the most salient and critical factors affecting the selection of a meeting destination. Despite the importance of the meeting industry in Japan, little academic research has been conducted, compared to rival countries in Asia. Therefore, the results of this study should enhance our understanding of the attributes that Japanese meeting planner choose.

\section{Literature review}

\subsection{Role of meeting planners}

Previous studies emphasize the importance of meeting planners and explain their roles. Meeting planners play a pivotal role in selecting destinations and venues [Lee and Back, 2005].

Hubbard, and Popovich [2000] point out the important skills for a hotel and conference center meeting planners. According to their study, communication, organizational, time management, and computer knowledge are cited as highly required skills. Especially in Japan, meeting planners have not been generally regarded as established profession yet. Therefore, there are relatively smaller numbers of people who identify themselves as meeting planners in Japan.

\subsection{Destination criteria}

Previous studies in terms of site selection criteria are as follows.

Oppermann [1996] carried out a questionnaire survey which consists of 15 decision criteria and asked respondents to indicate their importance in the destination selection process. The results showed that respondents regard meeting room facilities and hotel service quality as top priority.

Moreover, Lee [2009] did research about difference in opinion between Hotel Managers and Conference Organizers in Korea. Author found that facilities for the conference, staff fluency in major languages, competitiveness of the room rates, roads, accessibility were highly valued by the organizers.

Besides, the following papers discuss on comparative reviews of each country's representative exhibition cities. Kim, Sun, and Ap [2008] assessed the positioning of exhibition cities in Hong Kong, Beijing, Shanghai, Singapore, Seoul and Tokyo. The results of this study demonstrated that the Hong Kong and Singapore were viewed by conference participants as more preferable exhibition host destinations among the six compared cities in Asia.

In summary, even though meeting planners are key players in the destination selection process, there is little academic research which focuses on opinions of Japanese meeting planners. Thus, we identified a small area of research, which is about priorities of factors in the destination selections in Japan. 


\section{Data and method}

\subsection{Overview}

The target populations concerned in this study are meeting planners in Japan. The questionnaire is to examine their profiles and perception of site selection criteria. The attributes are based on the literature review dealing with meeting planners' site selection criteria. These attributes are exhibition service, accommodation, access, entertainment, sightseeing, and society. The destination selection is measured on a 5-point Likert scale of the importance, ranging from 1 (least important) to 5 (highly important).

\subsection{Data collection}

While a link to online survey has outreached recipients via list-serve of Meeting Professionals International Japan Chapter (MPI Japan Chapter), we collected complete responses of one hundred twenty-six, out of which 85 answers of meeting planners were deemed complete and usable for our analysis. Meeting Professionals International (MPI) is founded in 1972 and one of the the largest meeting planner and event planner industry association worldwide. MPI Japan Chapter was established in 1995.

\subsection{Data analysis}

The survey instrument was divided into two parts. The first part elicited demographic background information on respondents and the second consisted of 28 questions across 6 different domains designed to uncover how respondents evaluated the site selection. In addition to descriptive analysis, multivariate regressions were conducted using backward selection method on six dependent variables.

Main question analysed, thus treated as a dependent variable was the respondents' choices of the highest ratio of meeting related businesses for the last one year: Meeting, Incentive, Convention, Event, Exhibition and Other (MICE related events). Since ratio is continuous variable, multivariate regression analyses were performed. All assumptions and multicollinearity assumptions were verified and within acceptable range of between 1.3 and 2.4 .

Dependent variables are relative importance of the listed sub-categories for respondents, and we check for any significant associations with independent variables to verify their perception of important success factors for those sub-categories. The authors ask respondents' perception on relative importance of issues for meeting, incentive, convention, event, exhibition and others.

\section{Results}

\subsection{Characteristics of respondents}

The demographic profiles of the respondents are shown in Table 1. The gender composition of the respondents was $14.1 \%$ female and $85.9 \%$ male, showing that meeting professions in Japan appear to be more male-dominant than those in other nations. Majority of the respondents was between the ages of 35
Table 1: Demographic information of respondents

\begin{tabular}{lcc}
\hline \multicolumn{1}{c}{ Variables } & Frequency $(n)$ & Percent (\%) \\
\hline Gender & 12 & 14.1 \\
Female & 73 & 85.9 \\
Male & & \\
\hline Age & 4 & 4.7 \\
$18-24$ & 8 & 9.4 \\
$25-34$ & 24 & 28.2 \\
$35-44$ & 24 & 28.2 \\
$45-54$ & 18 & 21.2 \\
$55-64$ & 5 & 5.9 \\
65 or more & 2 & 2.4 \\
Prefer not to state & & \\
\hline Education & 4 & 4.7 \\
High school degree & 3 & 3.5 \\
Technical certificate, & 2 & 2.4 \\
Vocational school & 32 & 37.6 \\
2-year college & 29 & 34.1 \\
4-year college degree & 10 & 11.8 \\
Master's degree & 5 & 5.9 \\
Doctorate degree & & \\
Prefer not to state & & \\
\hline
\end{tabular}

and 54. 35-44 age group (28.2 \%) and 45-54 (28.2\%).

Concerning the education of respondents, majority of the respondents hold 4-year college degree (37.6 \%) and Master's degree $(34.1 \%)$.

\subsection{Measurement of destination selection}

Table 2 presents the importance of the destination selection factors for Japanese meeting planners. The 28 items were used to measure the site selection and categorized into six domains: exhibition service, accommodation, access, entertainment, sightseeing, and society.

In terms of "exhibition service", the item with the highest value was 'good venue management' $(M=4.40)$. The lowest mean score was 'presence or absence of day care center in the facility' ( $M=2.98)$. Regarding “accommodation”, the highest value was 'availability of modern hotel facility' $(M=4.46)$. This item was also the highest ranked of any of the 28 items.

Concerning the domain of "access", the highest evaluated item was 'easy access to host cities' $(M=4.40)$. The second highest item was 'convenient transportation system from airport/station to convention/exhibition' $(M=4.37)$. The domain "entertainment" ranked in the lower mean score than other domains. Mean score of 'shopping', 'availability of recreational resources', 'a variety of local festivals/events' and 'a variety of nightlife' was $3.28,3.28,3,37$, and 3.38 respectively.

In terms of "sightseeing", the highest ranked item was 'welldeveloped tourism infrastructure' $(M=4.26)$. Regarding "society", two items of 'friendly attitudes of residents for visitors' 
Table 2: Relative importance of issues among meeting planners in Japan

\begin{tabular}{|c|c|c|}
\hline Question item & Mean $(M)$ & Std. Deviation $(S D)$ \\
\hline \multicolumn{3}{|l|}{ Domain 1: Exhibition service } \\
\hline Good venue management & 4.40 & 0.928 \\
\hline Efficient promotion marketing strategy & 3.97 & 1.107 \\
\hline Availability of modern audio-visual equipment & 4.05 & 0.975 \\
\hline Reasonable rental fee of the venue & 4.38 & 0.938 \\
\hline Service quality of staff members serving in the venue & 4.32 & 0.991 \\
\hline Quality of local service providers, such as audio- visual vendors, interpreters etc. & 3.87 & 1.153 \\
\hline Number of available options of local service provider & 3.66 & 1.108 \\
\hline Reputation of the exhibition centers & 3.78 & 0.956 \\
\hline Reputation for having hosted successful events & 3.80 & 1.078 \\
\hline Well-developed facility for people with disability & 3.85 & 1.041 \\
\hline Presence or absence of day care center in the facility & 2.98 & 1.091 \\
\hline Safety and Security of the destination $\&$ venues & 4.39 & 0.989 \\
\hline \multicolumn{3}{|l|}{ Domain 2: Accommodation } \\
\hline Availability of Luxury hotel rooms & 3.78 & 1.016 \\
\hline Reasonable accommodation fees & 4.25 & 0.962 \\
\hline High level accommodation service & 3.95 & 0.975 \\
\hline Availability of modern hotel facilities & 4.46 & 0.933 \\
\hline \multicolumn{3}{|l|}{ Domain 3: Access } \\
\hline Reasonable local transportation fares & 3.65 & 1.077 \\
\hline Convenient transportation system from airport/station to convention/exhibition & 4.37 & 0.974 \\
\hline Easy access to host cities & 4.40 & 0.941 \\
\hline \multicolumn{3}{|l|}{ Domain 4: Entertainment } \\
\hline Shopping & 3.28 & 1.109 \\
\hline Availability of recreational resources & 3.28 & 1.053 \\
\hline A variety of local festivals/events & 3.37 & 1.056 \\
\hline A variety of nightlife & 3.38 & 1.091 \\
\hline \multicolumn{3}{|l|}{ Domain 5: Sightseeing } \\
\hline Beautiful scenery at host destination & 3.79 & 0.914 \\
\hline Many historical sites at host destination & 3.61 & 0.952 \\
\hline Well-developed tourism infrastructure (ex. ease of access, tourist facilities, etc) & 4.26 & 0.875 \\
\hline \multicolumn{3}{|l|}{ Domain 6: Society } \\
\hline Friendly attitudes of residents for visitors & 3.88 & 1.106 \\
\hline Destination with unique culture & 3.89 & 1.102 \\
\hline
\end{tabular}

and 'destination with unique culture' were mean scores $(M)$ of 3.88 and 3.89 respectively.

\subsection{Multivariate regression}

For meeting businesses, the most important variables with positive relationship were "friendly attitude of the locals" $(\beta=$ $.478, p \leq .001)$ and "availability of luxury hotels" $(\beta=.446, p$ $\leq .001)$. This implies that importance of those categories would increase as meeting planners businesses in the area of corporate meetings increase. On the other hand, relationship between amount of business with corporate meetings and "marketing strategy" $(\beta=-.258, p \geq .05)$, "reasonable rental fees" $(\beta=$ $-.223, p \geq .001)$ and "varieties of local events" $(\beta=-.408, p \leq$
.001) were negative.

For incentive businesses, positive relationship includes "quality of service providers" $(\beta=0.288, p \geq .05)$, "recreational resources" ( $\beta=0.182, p \geq .01)$ and "Infrastructure" $(\beta=0.242$, $p \geq .01)$. This implies that those factors are important to attract Incentive segment. On the other hand negative relationship were seen with variables such as "venue management" $(\beta=$ $-.42, p \geq .001)$ and "existence of day care centers" $(\beta=-0.28, p$ $\geq .05)$.

For convention businesses, positive relationship exists with variables such as "venue rental fees" $(\beta=.153, p<0.1)$, "day care centers" ( $\beta=.13, p \leq 0.1)$ and "reasonable accommodations" ( $\beta=.402, p \leq .05)$. On the other hand negative relation- 
T. Hara and H. Iwamoto: Analysis of Japanese meeting planners' profiles and site selection

Table 3: Multivariate regression analysis on relative importance on business segments

\begin{tabular}{|c|c|c|c|}
\hline Dependent Variable & Model & $\beta$ & $t$ \\
\hline \multirow{7}{*}{ Meeting } & Constant & 16.418 & 0.14 \\
\hline & Marketing Strategy & -0.258 & $-2.24 * *$ \\
\hline & Reasonable rental fees & -0.223 & $-1.98 * *$ \\
\hline & Variety of local events & -0.408 & $-3.01 * * *$ \\
\hline & Friendly attitude from locals & 0.478 & $3.39 * * *$ \\
\hline & Luxury Hotel & 0.466 & $4.46^{* * *}$ \\
\hline & $F=6.507$, Sig. $<.001, R-\mathrm{sq}=.279$ & & \\
\hline \multirow{7}{*}{ Incentive } & Constant & 10.02 & 1.23 \\
\hline & Venue Management & -0.423 & $-2.70 * * *$ \\
\hline & Quality of Local Service Providers & 0.288 & $2.13^{* *}$ \\
\hline & Day Care Centers & -0.283 & $-2.45 * *$ \\
\hline & Recreational Resources & 0.182 & 1.49 \\
\hline & Infrastructure & 0.242 & 1.55 \\
\hline & $F=3.14$, Sig. $<.05, R-\mathrm{sq}=0.158$ & & \\
\hline \multirow{7}{*}{ Convention } & Constant & 6.677 & 0.36 \\
\hline & Venue Rental Fee & 0.153 & 1.32 \\
\hline & Day Care Centers & 0.183 & 1.67 \\
\hline & Luxury Hotel Rooms & -0.270 & $-2.41 * *$ \\
\hline & Reasonable accommodation & 0.402 & $2.90 * *$ \\
\hline & Safety \& Security & -0.262 & $-1.95 * *$ \\
\hline & $F=3.86$, Sig. $<.05, R-\mathrm{sq}=0.19$ & & \\
\hline \multirow{9}{*}{ Event } & Constant & 13.56 & 1.18 \\
\hline & Audio-visual Equipment & 0.018 & 1.40 \\
\hline & Rental Fee of Venue & 0.232 & 1.89 \\
\hline & Local events & 0.373 & $2.58 * *$ \\
\hline & Friendly attitude from locals & -0.310 & $1.96 * *$ \\
\hline & Tourism Infrastructure & -0.441 & $-3.08 * * *$ \\
\hline & Reasonable accommodation & -0.245 & -1.74 \\
\hline & Safety \& Security & 1.278 & $2.01 * *$ \\
\hline & $F=3.04$, Sig. $<.05, R$-sq $=0.208$ & & \\
\hline \multirow{5}{*}{ Exhibition } & Constant & 0.994 & 0.11 \\
\hline & Unique Culture & 0.296 & $2.52 * *$ \\
\hline & Luxury Hotel & 0.226 & $1.97 * *$ \\
\hline & Reasonable Accommodation Fee & -0.275 & $-2.13 * *$ \\
\hline & $F=3.22$, Sig. $<.05, R-\mathrm{sq}=0.102$ & & \\
\hline \multirow{9}{*}{ Other } & Constant & 55.106 & 4.31 \\
\hline & Recreational Resources & 0.206 & 1.70 \\
\hline & Local events & 0.337 & $2.36 * *$ \\
\hline & Unique Culture & -0.460 & $-3.06 * *$ \\
\hline & Beautiful Scenery & -0.225 & $-1.99 * *$ \\
\hline & Luxury Hotel & -0.220 & $-1.99 * *$ \\
\hline & Convenient Transportation & 0.355 & $2.12^{* *}$ \\
\hline & Reasonable Accommodation Fee & -0.345 & $-2.09 * *$ \\
\hline & $F=4.81$, Sig. $<0.001, R-\mathrm{sq}=.3$ & & \\
\hline
\end{tabular}

Note: Significance levels $* * * \leq .001 * * \leq .05$. 
ship exists with variables such as "Luxury hotel rooms" ( $\beta=$ $-.27, p \leq .05)$ and "safety \& security" $(\beta=-.26, p \leq .05)$.

For events businesses, positive relationship exists with variables such as "audio-visual equipment availability" $(\beta=.018, p$ $\leq .1)$, "rental fee of a venue" $(\beta=.23, p \leq .1)$, "varieties of local evens" $(\beta=.37, p \leq .05)$ and "safety $\&$ security" $(\beta=.278, p \leq$ $.05)$. On the other hand, negative relationship exists with variable such as "friendly attitude from locals" $(\beta=-.31, p \leq .05)$, "tourism infrastructure" $(\beta=-.44, p \leq .05)$, and "reasonable accommodations" $(\beta=-.24, p \leq .05)$.

For exhibitions businesses, positive significant relationship exists with variables such as "unique culture" $(\beta=.29, p \leq .05)$, and "luxury hotels availability" $(\beta=.22, p \leq .05)$. On the other hand negative relationship exists with "reasonable accommodations" $(\beta=-.24, p \leq .05)$.

Finally, for other businesses, positive relationship exists with variables such as "recreational resources" $(\beta=.206, p \leq$ $.01)$, "local events" $(\beta=.33, p \leq .05)$, and "convenient transportation" ( $\beta=.35, p \leq .05) . P$ means $p$-value which is used in hypothesis testing. Sig means the significant level which is the probability that the event could have occurred by chance. $\beta$ indicates the unstandardized beta, while $\beta$ indicates standard partial regression coefficient. The $t$ static is the coefficient divided by its standard error.

On the other hand, negative relationship exists with variables such as "unique culture" ( $\beta=-.46, p \leq .05)$, "beautiful scenery" $(\beta=-.22, p \leq .05)$, "luxury hotel availability" $(\beta=-.22$, $p \leq .05)$, and "reasonable accommodations fee" $(\beta=-.34, p \leq$ $.05)$.

\section{Discussion}

This research in Japan showed that majority of the respondents were male. This study showed that more than half of respondents had 4-year college degree and Master's degree.

The results show that meeting planners in Japan place higher importance on factors of "good management system", "quality of staff members", "cost and access" when they select the destination. It may be noteworthy to state that education and training of staffs at meeting facilities should be emphasized to deliver "good management system" and "quality of staff members" which can only be improved through continuous education and training, while ease of access is viewed as a physical factor which is harder to rectify once the facilities have been developed.

Our analyses on relative importance of issues for sub-categories of MICE business, namely, meeting, incentive, convention, event, exhibition and others emphasize the importance of decomposing MICE into sub-categories as perception of relative importance in sub-categories are substantially different as shown in Table 3. We may have to use caution in interpreting negative associations of certain independent variables. We may have to rather see them as "(they) do not matter", instead of "decrease in X would cause increase in $Y$ " in negative relations. For example, existence of day care centers shows nega- tive signs to incentive businesses, while it shows positive signs to convention businesses. This can be interpreted that existence of day care centers are viewed as more important to attract convention businesses while it is perceived as less important to attract incentive businesses. Because independent variables are asking degree of relative importance in those issues, the interpretation becomes more important with $(+)$ sign and less important with (-) sign.

Another example of importance of MICE decomposition into sub-categories can be witnessed with the relative importance of "(availability of) luxury hotel rooms". Availability of luxury hotel rooms would be perceived highly important by subcategories of meeting businesses and exhibition businesses, while it is regarded less important by convention businesses and others. While some destination marketing organizations may be tempted to market MICE as one segment, the result of our analyses highlights importance of decomposition into subcategories to cater to the different needs and perceptions of relative importance of the same issues.

\section{Limitations and future research}

This study has limitation because of the limited number of the valid responses. Future research with higher numbers of valid responses would surely improve better results. Another research would be to ask international meeting planners, perhaps those based in other countries outside of Japan, to evaluate relative competitiveness of Japanese cities as meeting destinations.

\section{Acknowledgment}

This study was supported by JSPS KAKENHI Grant Number 20K12433. We acknowledge data collection facilitation by late Mr. Shin Asai, then Chairperson of the MPI Japan.

\section{References}

Kim, S. S., Sun, H., and Ap, J. (2008). Is there competition in the exhibition market in Asia?: Analysis of the positioning of major Asian exhibition host cities. Asia Pacific Journal of Tourism Research, Vol. 13, No. 3, 205-227.

Lau, C. K. H., Milne, S., and Johnston, C. S. (2005). MICE, ICT and local economic development: The case of Te Kahurangi, New Zealand. Journal of Convention \& Event Tourism, Vol. 7, No. 1, 61-75.

Lee, M. J. and Back, K-J. (2005). A review of convention and meeting management research 1990-2003. Journal of Convention \& Event Tourism, Vol. 7, No. 2, 1-20.

Lee, T. J. (2009). The successful conference venue: perceptions of conference organizers and hotel managers. Event management, Vol. 13, No. 3, 171-180.

Oppermann, M. (1996). Convention destination images: Analysis of association meeting planners' perceptions. Tourism Management, Vol. 17, No. 3, 175-182.

Pearlman, D. M. \& Mollere, L. (2009). Meetings, incentive, convention, and exhibition evaluation practices: An ex- 
ploratory study among destination marketing organizations. Journal of Convention \& Event Tourism, Vol. 10, No. 3, 147165.

Sheehan, A. L., Hubbard, S. S., and Popovich, P. M. (2000). Profiling the hotel and conference center meeting planner. Journal of Convention \& Exhibition Management, Vol. 2, Nos. 2-3, 11-25.

(Received January 7, 2021; accepted April 15, 2021) 